\title{
Physical and hygienic-sanitary conditions of poultry slaughterhouses in the municipality of Parnaíba, Piauí, Brazil
}

\author{
Condições físicas e higiênico-sanitárias dos estabelecimentos \\ de abate de frangos do município de Parnaíba, Piauí, Brasil
}

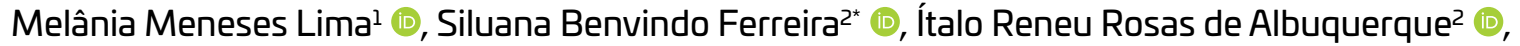 \\ Carlos Kaiser Ferreira de Meneses ${ }^{3}$ (D) , Lauro César Soares Feitosa ${ }^{4}$ (1), Katiene Regia Silva Sousa 5 (D), \\ Isabel Azevedo Carvalho ${ }^{5}$
}

\begin{abstract}
This study aimed to evaluate the physical and hygienic-sanitary conditions of poultry slaughterhouses in the municipality of Parnaíba, Piauí, Brazil. Ten slaughterhouses were visited, using a checklist as an evaluation criterion, seeking to assess the physical and hygienic-sanitary conditions of facilities, equipment, handlers, environment, production, and food transportation, during the entire slaughtering process, to verify compliance with current legislation. The slaughterhouses visited $(10 / 100 \%)$ had no Official Inspection Service and did not obey the rules established by legislation, showing precarious physical and hygienic-sanitary conditions of operation. Most of the establishments $(9 / 90 \%)$ were located in the urban area and one $(10 \%)$ in the rural area. None of them followed the animal welfare recommendations. Moreover, seven (70\%) establishments had no waste treatment and the residues were dumped in an open area. Therefore, it was concluded that the hygienic-sanitary conditions of poultry slaughterhouses in Parnaíba pose risks to meet quality and the health of slaughterhouses employees and people who consume the products from those establishments.
\end{abstract}

KEYWORDS: Food security; Chicken; Public health.

RESUMO: Objetivou-se avaliar as condições físicas e higiênico-sanitárias dos estabelecimentos de abate de frango, no município de Parnaíba, estado do Piauí. Foram visitados 10 estabelecimentos de abate, sendo utilizado como critério avaliativo da pesquisa um checklist, que buscou avaliar as condiçóes físicas e higiênico-sanitárias das instalaçóes, equipamentos, dos manipuladores, ambiente, como também, da produção, assim como, transporte do alimento durante todo o processo de abate para averiguar conformidade com a legislaçáo vigente. Todos os abatedouros visitados (10) $100 \%$ não apresentavam Serviço de Inspeção Oficial e encontravam-se fora das normas estabelecidas pela legislação, com condições físicas e higiênico-sanitárias precárias de funcionamento. A grande maioria dos estabelecimentos, (9) 90\% encontravam-se localizados na zona urbana e um $(10 \%)$ na zona rural. Estes não seguiam as recomendaçóes de bem-estar animal voltado as atividades. Ainda, (7) $70 \%$ dos estabelecimentos não realizavam tratamento dos resíduos, sendo despejados a céu aberto. Portanto, concluiu-se que as condiçóes higiênico-sanitárias dos abatedouros da cidade de Parnaíba proporcionam riscos à qualidade da carne, à saúde dos funcionários dos abatedouros e da populaçáo que consome os produtos provenientes desses estabelecimentos.

PALAVRAS-CHAVE: Segurança alimentar; Aves; Saúde pública.

\section{INTRODUCTION}

Brazil is among the largest food producers in the world, with emphasis on poultry, ranking third as a producer and leader in exports. According to data from the Brazilian Association of Animal Protein (ABPA), poultry production in Brazil was 13.45 million tons, in 2019, with a per capita poultry consumption of $42.84 \mathrm{~kg} /$ inhabitant $/$ year, since this meat is a great alternative due to its nutritional benefits and affordable price (ABPA, 2020).

Animal products, especially poultry, are considered an important source of protein for humans, due to their high 
protein content. However, they are not free from health risk, as their richness in protein, poultry neutral $\mathrm{pH}$, high water content, and available nutrients contribute to the rapid deterioration of the product, as well as the survival and multiplication of numerous pathogenic microorganisms that cause Foodborne Diseases (FBDs), which can cause high economic and social losses (OLIVEIRA et al., 2011; GERMANO; GERMANO, 2019).

The World Health Organization (WHO) has warned of the need to curb food contamination by biological agents with the potential to cause damage to health, which includes inadequate conditions in the production chain (OMS, 2002; MARINS et al., 2014). Thus, inspection bodies, as well as all professionals in the poultry production chain, especially veterinarians working both as technical officers and as those responsible for sanitary inspection in their different areas, should take the commitment to participate in the animal food industry, thus providing safe products for humanity (BENEVIDES, 2015).

Given the above, this study aimed to assess the physical and hygienic-sanitary conditions of poultry slaughterhouses in the municipality of Parnaíba (Piauí, Brazil).

\section{MATERIAL AND METHODS}

This study was approved (protocol No. 2,944,087) by the Ethics and Research Committee of UEMA - Center for Higher Studies of Caxias, State University of Maranhão.

The research was conducted in the municipality of Parnaíba, northern Piauí, Brazil, from July to September 2018, when 10 poultry slaughterhouses were assessed. The hygienic-sanitary conditions, buildings, equipment maintenance and hygiene, handlers' hygiene, location conditions, facilities, slaughter procedures, production, transportation, and destination of the final product were assessed for later data analysis.

Slaughterhouses were surveyed in the municipality of Parnaíba, based on data from the Sanitary Surveillance and information provided by the population, and 15 establishments were identified, of which only 10 were in operation. These slaughterhouses were coded as A, B, C, D, E, F, G, H, $\mathrm{I}$, and J. The authorized representatives of the establishments signed the "Informed Consent Form" for research consent.

The poultry slaughterhouses were evaluated regarding their physical and hygienic-sanitary conditions through a checklist in a form, with items including the following observations: Ibuilding and facilities, II- equipment, furniture and utensils, III- handlers, and IV- food production and transportation. The items were arranged in "conforming", "non-conforming", and "non-applicable" according to ANVISA Ordinance No. 326, of July 30, 1997 (Brasil, 1997).

The items were divided into critical points and non-critical points. The critical points were those considered of paramount importance, by current legislation, for the process development with the final quality of the product, ensured by inspection, so the establishment would be considered suitable for marketing the product. The non-critical points were those in which, according to legislation, the danger of contamination is not imminent.

The data were tabulated and presented using descriptive statistics, as percentage relative frequency, for each item checked during visits.

\section{RESULTS AND DISCUSSIONS}

All visited slaughterhouses (10/100\%) had neither an Official Inspection Service nor veterinarians to perform ante-and post-mortem inspection, which was an illegal practice observed. The role played by these professionals is highly important for public health preventive measures as they supervise and ensure compliance with hygienic-sanitary standards and humane slaughter practices, thus ensuring food safety of products from slaughterhouses, avoiding that meat unfit for consumption or that may be potentially harmful to human health become available for consumers (MORAIS et al. 2017; DUARTE; AFONSO, 2020).

The results from the evaluation of the facilities, location, and physical and hygienic-sanitary conditions of the establishments are shown in Table 1. The slaughterhouses visited had no physical facilities designed for slaughtering but were adapted for this activity. Moura et al. (2015) found that the physical structure of slaughterhouses in the state of Rio Grande do Norte was inadequate when compared to the parameters required by current legislation (BRASIL, 1997; BRASIL, 1998). A precarious state of processing was observed in all establishments, with no security for the final product quality. Several important stages must be followed during the poultry slaughter process, such as bird reception, stunning, bleeding, scalding, plucking, and evisceration, which need to be planned so that they can be carried out efficiently and hygienically.

All slaughterhouses were located in their owners' homes, nine $(90 \%)$ were in the urban area and one $(10 \%)$ was in the rural area. Leite et al. (2009), analyzing slaughterhouses in Rio Grande do Norte, and Morais et al. (2017), in the state of Paraíba, found that most establishments were located in urban areas, which caused discomfort to nearby residents, due to the production of unpleasant odors, in addition to attracting insects and rodents. In fact, slaughterhouses in these areas increase the potential risk of transmission of numerous diseases, representing a risk to public health.

Regarding the physical facilities, the slaughterhouses were in precarious conditions of operation, which increases the possibility of cross-contamination related to the facilities, equipment, and handlers. Eighty percent of the establishments had bathrooms (Table 1) in poor conditions, and $20 \%$ had no bathroom. There were also no lockers and changing rooms in the visited slaughterhouses, so employees kept their belongings inside the production area or somewhere nearby. Similar results were found by Morais et al. (2017), 
who observed that $80.3 \%$ of the slaughterhouses in Paraíba were not able to be used.

None of the establishments had adequate lighting and ventilation (Table 1), as they had neither protection against lamp breakage nor exhaust fans in the production and handling areas. Leite et al. (2009) reported that nine $(60 \%)$ of the small slaughterhouses they visited had inadequate lighting, affecting the inspection service, which corroborates the results of our study; however, regarding the ventilation system, the establishments were insufficiently ventilated.

Concerning the hygienic condition of the facilities, two (20\%) establishments met the required standards (Table 1); however, they had no exclusive employees for this task. Some slaughterhouses had no criteria and care for the hygiene of the facilities. According to Assis et al. (2019), the lack of standardization of facilities, equipment, and utensils, associated with hygiene failures during the technological process of food animal products, compromises the identity and safety of these products.

The integrated control of vectors and urban pests was one of the most critical points identified, as only one (10\%) establishment was in compliance with this requirement, regularized by a company regulated and specialized in pest control, whereas in nine $(90 \%)$ slaughterhouses there was no vector/pest control, which may result in harm to human health.

Seven establishments (70\%) had water supply from other sources (such as wells) instead of public water supply. However, any slaughterhouse had potability attested by laboratory report, with adequate periodicity, signed by a technician responsible for the water analysis or issued by an outsourced company. Potable water is of great importance for the food industry, as it directly influences the final product quality (Brasil, 2004).
After all, there are numerous contaminants carried by water, such as bacteria, viruses, parasites, natural toxins, chemicals, pesticides, among others. Alhaji; Baiwa (2015), assessing the factors that affect the hygienic-sanitary operations in slaughterhouses in north-central Nigeria, observed that most of the assessed establishments had no adequate supply of potable water, refrigeration, and efficient sewage systems or waste disposal.

Regarding waste management and sewage treatment, seven (70\%) establishments (Table 1) had no waste treatment and the residues were dumped in an open area. The residues were removed daily from the production area; however, there were no collection containers, easy to clean and transport, properly identified, and constantly sanitized. In the other three (30\%) establishments, the septic tanks and sewage were connected to the public sewage network and there were grease traps in an adequate state of conservation and operation. The slaughter process generates different types of waste that need to be correctly managed to mitigate possible environmental impacts and the spread of infectious agents; moreover, how waste is dumped directly influences the environment (physically, biotically, and socioeconomically), causing losses in the surrounding communities, sometimes irreparable (SILVA; NETO, 2018).

None of the establishments had sanitary barriers (footbath, boot-bath, sinks for hand hygiene, detergent and sanitizing solutions, paper towels, and foot-pedal trash can) to prevent the presence of microorganisms in the production area (Table 2).

Concerning the official rules and determinations relating to animal welfare, there was no concern for bird housing conditions in slaughterhouses visited, as according to current legislation, animals awaiting slaughter cannot be subjected to ill-treatment or any condition that causes stress or physical or

Table 1. Frequency of points in compliance with current legislation, relating to buildings and facilities of poultry slaughterhouses in Parnaíba (Piauí, Brazil).

\begin{tabular}{|c|c|c|c|c|c|c|c|c|c|c|c|}
\hline \multicolumn{12}{|c|}{ Establishments } \\
\hline Items & $\mathbf{N}$ & 1 & 2 & 3 & 4 & 5 & 6 & 7 & 8 & 9 & 10 \\
\hline Floor & 2 & $100 \%$ & $100 \%$ & $100 \%$ & $100 \%$ & $0 \%$ & $0 \%$ & $0 \%$ & $0 \%$ & $0 \%$ & $100 \%$ \\
\hline $\begin{array}{l}\text { Sanitary facilities and } \\
\text { changing rooms }\end{array}$ & 6 & $0 \%$ & $50 \%$ & $83.3 \%$ & $0 \%$ & $0 \%$ & $0 \%$ & $0 \%$ & $0 \%$ & $0 \%$ & $33.32 \%$ \\
\hline $\begin{array}{l}\text { Lighting and electrical } \\
\text { installations }\end{array}$ & 1 & $0 \%$ & $0 \%$ & $0 \%$ & $0 \%$ & $0 \%$ & $0 \%$ & $0 \%$ & $0 \%$ & $0 \%$ & $0 \%$ \\
\hline $\begin{array}{l}\text { Ventilation and air } \\
\text { conditioning }\end{array}$ & 2 & $0 \%$ & $50 \%$ & $0 \%$ & $0 \%$ & $0 \%$ & $0 \%$ & $0 \%$ & $0 \%$ & $0 \%$ & $0 \%$ \\
\hline Hygiene of facilities & 2 & $100 \%$ & $100 \%$ & $0 \%$ & $50 \%$ & $50 \%$ & $0 \%$ & $0 \%$ & $0 \%$ & $0 \%$ & $0 \%$ \\
\hline Pest control & 2 & $50 \%$ & $100 \%$ & $50 \%$ & $50 \%$ & $50 \%$ & $50 \%$ & $50 \%$ & $50 \%$ & $50 \%$ & $50 \%$ \\
\hline Water supply & 5 & $0 \%$ & $0 \%$ & $40 \%$ & $0 \%$ & $0 \%$ & $40 \%$ & $20 \%$ & $0 \%$ & $20 \%$ & $20 \%$ \\
\hline Waste management & 2 & $50 \%$ & $50 \%$ & $100 \%$ & $0 \%$ & $0 \%$ & $0 \%$ & $50 \%$ & $50 \%$ & $0 \%$ & $0 \%$ \\
\hline Sewerage & 1 & $100 \%$ & $100 \%$ & $100 \%$ & $0 \%$ & $0 \%$ & $0 \%$ & $0 \%$ & $0 \%$ & $0 \%$ & $0 \%$ \\
\hline Layout & 1 & $0 \%$ & $100 \%$ & $0 \%$ & $100 \%$ & $0 \%$ & $0 \%$ & $0 \%$ & $0 \%$ & $0 \%$ & $0 \%$ \\
\hline
\end{tabular}

$\mathrm{N}$ : number of critical points assessed. 
psychological suffering (BRASIL, 2000). Therefore, for the proper functioning of the process, the activities and areas where poultry will be housed and slaughtered need to be organized (CATHARIN; SACHUK, 2012).

None of the establishments was in compliance with current legislation as for equipment, furniture, and utensils (Table 2). In $60 \%$ of the slaughterhouses, there was metal equipment but in precarious conditions, without maintenance, very dirty, and even rough. In the other $40 \%$, we found non-corrosionresistant equipment. The equipment and machines used in slaughterhouses must be specially tailored to help achieve the highest quality of food products. Those made of stainless steel should be preferred (for better hygiene), with no creases/protrusions in which organic matter may accumulate, leading to the appearance of contamination foci (VEGRO; ROCHA, 2007).

Four $(40 \%)$ establishments had no food preservation equipment (refrigerators, freezers, cold chambers, among others) because, after being slaughtered, the birds were sold without being refrigerated, called by the owners of the establishments as "warm poultry". This procedure was observed in the artisanal and industrial slaughter of poultry, sold in Recife (Pernambuco State, Brazil), in which non-refrigerated poultry carcasses, from artisanal slaughter, had higher contamination than refrigerated carcasses from industrial slaughter (MOURA FILHO et al., 2011).

Five (50\%) establishments had utensils (Table 2) made of non-contaminating material, resistant to corrosion, in good state of conservation, sufficient number, and appropriate to the type of operation. However, the other $50 \%$ had utensils made of wood, which is not recommended by current legislation, as wood contains a porous and permeable surface, with roughness, and is difficult to sanitize, which may contribute to product contamination.

Machado et al. (2013) found only one establishment in $100 \%$ compliance with the utensils, whereas the other slaughterhouses had compliance rates below $80 \%$, mainly due to poor conservation and hygiene of materials. These authors also observed that $55.55 \%$ of the establishments were not in compliance with any of the analyzed items and emphasized the inadequacy of the benches ( $86.67 \%$ of the establishments), which were made of wood, increasing the risk of food contamination by microorganisms.

Eight $(80 \%)$ establishments had neither records proving the calibration of measuring instruments and equipment nor documents proving their calibration by outsourced companies. In addition, they had neither (proven able) professionals responsible for the sanitation process nor frequency records of sanitization of equipment, machines, furniture, and utensils.

Regarding the handlers (Table 3), none of the establishments met the standards established by current legislation. These employees are important vehicles for the spread of microorganisms, and hand hygiene is one of the most important procedures for reducing foodborne outbreaks (DJEKIC et al., 2016). Only three (30\%) establishments were $100 \%$ in compliance with the handlers' hygiene practices. Behaviors such as no hand washing (before, during, and after poultry slaughtering), the use of adornment, among others, may facilitate the transmission of microorganisms from handlers to meat, compromising the product final quality and posing a risk to consumers' health, due to the possibility of food poisoning; therefore, these behaviors must be combated through Good Handling Practices (MOURA et al., 2015).

Table 2. Frequency of critical points in compliance with legislation, relating to equipment, furniture, and utensils in poultry slaughterhouses in Parnaíba (Piauí, Brazil).

\begin{tabular}{|c|c|c|c|c|c|c|c|c|c|c|c|}
\hline \multicolumn{12}{|c|}{ Establishments } \\
\hline Items & N & 1 & 2 & 3 & 4 & 5 & 6 & 7 & 8 & 9 & 10 \\
\hline Equipment & 3 & $33.3 \%$ & $33.3 \%$ & $66.7 \%$ & $0 \%$ & $33.3 \%$ & $0 \%$ & $66.7 \%$ & $0 \%$ & $0 \%$ & $33.3 \%$ \\
\hline Furniture & 1 & $0 \%$ & $100 \%$ & $100 \%$ & $100 \%$ & $100 \%$ & $50 \%$ & $100 \%$ & $0 \%$ & $0 \%$ & $100 \%$ \\
\hline Utensils & 1 & $0 \%$ & $100 \%$ & $100 \%$ & $100 \%$ & $0 \%$ & $50 \%$ & $0 \%$ & O\%С & $0 \%$ & $100 \%$ \\
\hline Machinery cleaning & 4 & $33.3 \%$ & $100 \%$ & $75 \%$ & $100 \%$ & $66.7 \%$ & $50 \%$ & $50 \%$ & $66.7 \%$ & $75 \%$ & $66.7 \%$ \\
\hline
\end{tabular}

$\mathrm{N}$ : number of critical points assessed.

Table 3. Frequency of critical points in compliance with legislation, relating to handlers in poultry slaughterhouses in Parnaíba (Piauí, Brazil)

\begin{tabular}{|c|c|c|c|c|c|c|c|c|c|c|c|}
\hline \multicolumn{12}{|c|}{ Establishments } \\
\hline Items & $\mathbf{N}$ & 1 & 2 & 3 & 4 & 5 & 6 & 7 & 8 & 9 & 10 \\
\hline Clothing & 2 & $75 \%$ & $0 \%$ & $100 \%$ & $50 \%$ & $100 \%$ & $0 \%$ & $50 \%$ & $0 \%$ & $0 \%$ & $75 \%$ \\
\hline Hygiene habits & 2 & $100 \%$ & $50 \%$ & $100 \%$ & $50 \%$ & $50 \%$ & $50 \%$ & $66,7 \%$ & $100 \%$ & $0 \%$ & $50 \%$ \\
\hline Health condition & 1 & $100 \%$ & O\%С & $100 \%$ & $100 \%$ & $100 \%$ & $0 \%$ & $0 \%$ & $100 \%$ & $0 \%$ & $0 \%$ \\
\hline PPE & 1 & $100 \%$ & $100 \%$ & $100 \%$ & $0 \%$ & $100 \%$ & $0 \%$ & $0 \%$ & $100 \%$ & $0 \%$ & $0 \%$ \\
\hline Handlers training & 1 & $0 \%$ & $100 \%$ & $100 \%$ & $100 \%$ & $0 \%$ & $0 \%$ & $0 \%$ & $0 \%$ & $0 \%$ & $0 \%$ \\
\hline
\end{tabular}

$\mathrm{N}$ : number of critical points assessed; PPE: Personal Protective Equipment. 
Table 4. Frequency of critical points in compliance with legislation, relating to food production and transportation in poultry slaughterhouses in Parnaíba (Piauí, Brazil).

\begin{tabular}{|c|c|c|c|c|c|c|c|c|c|c|c|}
\hline \multicolumn{12}{|c|}{ Establishments } \\
\hline Items & $\mathbf{N}$ & 1 & 2 & 3 & 4 & 5 & 6 & 7 & 8 & 9 & 10 \\
\hline $\begin{array}{l}\text { Raw material. ingredients } \\
\text { and packaging }\end{array}$ & 4 & $50 \%$ & $100 \%$ & $50 \%$ & $66.7 \%$ & $0 \%$ & $0 \%$ & $50 \%$ & $0 \%$ & $0 \%$ & $0 \%$ \\
\hline Production flow & 1 & $0 \%$ & $0 \%$ & $0 \%$ & $100 \%$ & $0 \%$ & $0 \%$ & $0 \%$ & $0 \%$ & $0 \%$ & $0 \%$ \\
\hline $\begin{array}{l}\text { Labeling and storage of } \\
\text { the final product }\end{array}$ & 6 & $50 \%$ & $100 \%$ & $33.3 \%$ & $33.3 \%$ & $33.3 \%$ & $33.3 \%$ & $50 \%$ & $20 \%$ & $50 \%$ & $0 \%$ \\
\hline Quality control & 2 & $0 \%$ & $0 \%$ & $0 \%$ & $0 \%$ & $0 \%$ & $0 \%$ & $0 \%$ & $0 \%$ & $0 \%$ & $0 \%$ \\
\hline $\begin{array}{l}\text { Final product } \\
\text { transportation }\end{array}$ & 4 & $0 \%$ & $50 \%$ & $75 \%$ & $N / A$ & $0 \%$ & $0 \%$ & $0 \%$ & $0 \%$ & $0 \%$ & $0 \%$ \\
\hline
\end{tabular}

N/A: non-applicable; N: number of critical points assessed.

Two (20\%) establishments had employees wearing uniforms in an adequate condition (Table 3); however, the other slaughterhouses' employees worked shirtless or wearing precarious and dirty clothes, with unprotected hair and barefoot. Workers, in all establishments, had no periodic medical examinations and their health cards were not required, which was also reported by Leite et al. (2009). Furthermore, regular training for handlers was observed in only $30 \%$ of slaughterhouses. According to Goés et al. (2001), education and periodic training for food handlers are very important to obtain and maintain the hygienicsanitary quality of food products because many food poisonings are related to food contamination by handlers.

The production, flowchart, final product quality control, and transportation (Table 4) were the critical points with the lowest quality control, in the production process. In fact, $100 \%$ of the establishments had no quality control practices. These results corroborate those found by Dantas et al. (2017), in slaughterhouses in the "Sertão" region of Paraíba. These authors observed that there was no manual of good manufacturing practices and quality control, i.e., most establishments had no internal procedures to ensure their product quality and, consequently, most of the time, they did not meet the sanitary standards, given the various irregularities in the hygienic-sanitary conditions identified in such research.
The final product transportation occurs inappropriately through open vehicles, without temperature control, increasing the risk of physical, biological, and chemical contamination, as well as the loss of nutritional quality of the product offered to the consumer. Brazilian legislation is clear in terms of food animal product transportation, determining that vehicles, containers, or compartments used to transport raw materials and refrigerated products must have thermal insulation and, when necessary, cold generating equipment, in addition to a temperature control instrument (BRASIL, 2020).

\section{CONCLUSIONS}

The slaughterhouses in the municipality of Parnaíba were not in compliance with current legislation, as they were located in inappropriate areas, with extremely poor hygienic-sanitary conditions and physical facilities inadequate for their purpose, not meeting the standards that ensure animal welfare, consumer safety, handlers health, and the prevention of environmental contamination. It is clear that the slaughterhouses in Parnaíba (Piauí, Brazil) urgently need intervention by public authorities and stricter inspections, putting into practice the precepts of Brazilian legislation in this sector.

\section{REFERENCES}

ABPA.Associação Brasileira de ProteínaAnimal. RelatórioAnual 2020. Disponívelem:<https:/abpa-br.org/wp-ontent/uploads/2020/05/abpa_ relatorio_anual_2020_portugues_web.pdf >.Acesso em:10 jan.2021.

ALHAJI, N. B.; BAIWA, M. Factors affecting workers' delivery of good hygienic and sanitary operations in slaughterhouses in north-central Nigeria. Sokoto Journal ofVeterinary Sciences, v.13, n. 1, p. 29-37, 2015.

ASSIS, D. C. S. et al. Caracterização microbiológica, físico-química e das condições de produção e comercialização da carne de sol de Salinas, Minas Gerais. Arquivo Brasileiro de Medicina Veterinária e Zootecnia, v. 71, n. 6, p. 1985-1992, 2019.
BRASIL. Ministério da Saúde. Portaria 326 de 30 de julho de 1997. Regulamento técnico sobre as condições higiênico-sanitárias e de boas práticas de fabricação para estabelecimentos produtores/industrializadores de alimentos. Brasília, 1997. Disponível em: <http:/http://bvsms.saude.gov.br/bvs/ saudelegis/svsl/1997/prt0326_30_07_1997.html>. Acesso em: 03 set. 2018.

BRASIL, Ministério da Agricultura Pecuária e Abastecimento. Portaria 210 de 10 de novembro de 1998. Regulamento Técnico da Inspeção Tecnológica e Higiênico-Sanitária de Carnes de Aves. Brasília, 1998. 
BRASIL, Ministério da Agricultura Pecuária e Abastecimento. Instrução Normativa 03 de 17 de janeiro de 2000. Regulamento Técnico de Métodos de Insensibilização Para o Abate Humanitário deAnimais de Açougue. Brasília, 2000. Disponível em: <http:/www. agricultura.gov.br/assuntos/sustentabilidade/bem-estaranimal/ arquivos/arquivos-legislacao/in-03-de-2000.pdf>. Acesso em: 19 nov. 2018.

BRASIL, Ministério da Saúde, ANVISA. Resolução - RDC 216, de 15 de setembro de 2004. Dispõe sobre Regulamento Técnico de Boas Práticas para Serviços de Alimentação. Brasília: Diário Oficial da União, 2004.

BRASIL, Ministério da Agricultura, Pecuária e do Abastecimento (MAPA). Decreto n 9.013, de 29 de Março de 2017, alterado pelo Decreto $n^{\circ} 10.468$, de 18 de agosto de 2020. Regulamento de Inspeção Industrial e Sanitária de Produtos de Origem Animal (RIISPOA). Brasília: MAPA; 2020. Disponível em: <https:/ www.in.gov.br/en/web/dou/-/decreto-n-10.468-de-18-deagosto-de-2020-272981604>. Acesso em: 20 dez. 2020.

BENEVIDES, W. S. Processos de abate de aves: industrial e a outra realidade. Ciência Animal, v. 25, n. 01, p. 155-166, 2015.

CATHARIN, K.; SACHUK, M. I. O significado do trabalho para as agricultoras familiares inseridas no "Programa Avicultura Colonial" no estado do Rio Grande do Sul. Qualitas Revista Eletrônica, v. 13, 2012.

DANTAS, R. P. et al. Avaliação das condições higiênico-sanitárias de frigoríficos do sertão paraibano. Revista Brasileira de Gestão Ambiental, v. 1l, n. 2, p. 25 -31, 2017.

DJEKIC, I. et al. Effects of HACCP on process hygiene in different types of Serbian food establishments. Food Control, v. 60, p. 131$137,2016$.

DUARTE, F. H. G.; AFONSO, M. L. M. Abate de animais para consumo: Tese e antítese do bem estar animal e dos princípios da medicina veterinária. Brazilian Journal of Development, v. 6, n. 6, p. 35854-35874, 2020

GERMANO, P. M. L; GERMANO, M. I. S. Higiene e Vigilância Sanitária dos Alimentos. 6. ed. Barueri: Manole, 2019.
GÓES, J. A. W. et al. Capacitação dos manipuladores de alimentos e a qualidade da alimentação servida. Higiene Alimentar, v. 15, n. 82, p. 20-22, 2001.

LEITE, A. I. et al. Condições Físicas e Higiênico-sanitárias dos Matadouros Municipais da Região Oeste do Rio Grande do Norte, Brasil. Arquivos do Instituto Biológico, v. 76, p. 335-340, 2009.

MACHADO, S. S. et al. Avaliação do perfil higiênico-sanitário dos estabelecimentos comerciais e manipuladores de carne e derivados em feiras livres. In: SAFETY, HELTH AND ENVIRONMENT WORLD CONGRESS, 13., 2013. Anais... Porto, 2013. Disponíel em: <http:/copec. eu/congresses/shewc2013/proc/works/62.pdf>.Acesoem:20nov.2018.

MARINS, B. R.; TANCREDI, R. C. P.; GEMAL, A. L. Segurança alimentar no contexto da vigilância sanitária: reflexões e práticas. Rio de Janeiro: EPSJV, 2014

MORAIS, D. F. et al. Condições físicas e higiênico-sanitárias dos abatedouros da Paraíba, Nordeste do Brasil. Revista Brasileira de Ciências Veterinárias, v. 24, n. 4, p. 201-206, 2017.

MOURA, E. S. R. et al. Perfil higiênico-sanitário e perigos microbiológicos em abatedouros públicos. Revista Brasileira de Medicina Veterinária, v. 3, p. 203-208, 2015.

MOURA FILHO, L. G. M. et al. Perfil microbiológico da carne de frangos abatidos artesanalmente e na indústria, comercializados na grande Recife-PE. Medicina Veterinária, v. 1, p. 12-17, 2010.

OLIVEIRA, A. V. B. et al. Padrões microbiológicos da carne de frango de corte-referencial teórico. Revista Verde, v. 6, n. 3, p. 01-16, 2011.

OMS. Organização Mundial de Saúde. Food safety and food borne illness. Genebra, 2002.

SILVA, G. S. O.; NETO, O.J. A. G. Análise dos impactos socioambientais gerados por descartes de efluentes de abatedouros no bairro Maracanã, São Luis - MA. Revista Interdisciplinar em Cultura e Sociedade (RICS), v. 4, 2018.

VEGRO, C. L. R.; ROCHA, M. B. Expectativas tecnológicas para o segmento de carnes de aves e suínos. Informações Econômicas, v. 37, n. $5,2007$. 